\title{
PROLOGUE: TERROR AND HEALING IN EL SALVADOR
}

In dents of San Salvador found themselves caught in an eerie déjà vu. On March 6 , 2000 , hundreds of riot police, in an action reminiscent of the war years, fired tear gas into a hospital emergency room occupied by protesting health workers, then stormed the building. At least two patients died in the chaos and dozens were injured. The violence came during a prolonged health strike that had paralyzed hospitals across the country as two medical unions protested President Francisco Flores's plans to privatize social security health services.

Under pressure, Flores, of the right-wing National Republican Alliance (ARENA) party, backed off on his privatization plan only to unveil a new version of the plan months later. By fall 2002 the opposition, now joined by public hospital employees and a broad sector of the democratic left, struck again with health strikes, road closings, and a series of massive "White Marches" in which hundreds of thousands filled the streets dressed in white to show solidarity with striking doctors and nurses. Once again efforts by ARENA elites backed by multilateral lenders favoring privatization were set back. In June 2003 Flores agreed to a joint health reform commission that would include leaders of the social movement. After that, in a rare move, the World Bank agreed to remove privatization conditions from loan agreements.

The marches were the largest street mobilizations since the war ended, and to the surprise of many, they were not led by the leftist party of former guerrillas-the Farabundo Martí National Liberation Front (FMLN) - whose leaders had belatedly thrown their support behind the radicalized health workers after the protests gained popular momentum. In retrospect, given the frustrations of polarized party politics in El Salvador, many observers credit the credibility and legitimacy of the organized physicians for the success of the mobilizations. It is rare for medical professionals to leave the relative comfort of medical practice to lead political movements. However, health workers have played critical roles for many years in El Salvador's volatile politics. Three recent mayors of San Salvador have been doctors, including leftists Violeta Menjívar and Hector Silva, who are credited with initiating innovative community health strategies 
in urban barrios, and Norman Quijano, the ARENA candidate who narrowly defeated Menjívar in January 2009.

This ethnography tells the story of contemporary struggles over health rights in El Salvador and builds a theoretical argument for the role of the "body politic," a concept that seeks to restore materiality and practice in dialectical understandings of political power and social movements. Most of my fieldwork was carried out during the mid-I99os peace process that followed the twelveyear civil war, with a focus on a "popular" health system built by the FMLN, dissident peasants, and nongovernmental organizations (NGOs) in northeast Chalatenango, a mountainous region that served as a rearguard for guerrillas during the war. I studied efforts of the ARENA-led Ministry of Health to regain control over health in the former war zone during the I99os, and conversely, the struggles of the popular health movement to reform the ministry's rural health policies. ${ }^{\mathrm{I}}$ More recent research from 2000 to 2007 focused on the social movement behind the White Marches as health workers led a national mobilization against privatization. My research has been shaped by previous experiences in El Salvador investigating military impacts on health work as a volunteer with health rights NGOs in 1985-1989 and reporting on the war for U.S. newspapers from 1987 through early 1990.

From a political "realist" perspective, it takes a certain moxie to insist on human health as any sort of criteria during a war, especially during the early I980s when the political murder rate had soared to one thousand souls a month. The exercise becomes more macabre, stepping back a little more from the bloodbath, when one considers the statistics on agricultural modernization backed by military repression since the I96os, which relegated hundreds of thousands of campesino small-holders to a marginalized existence as seasonal or surplus labor. In truth, hardly anyone in the privileged north had paid attention to rural El Salvador before the shooting began in the late I970s. International attention was focused on the successful Nicaraguan rebellion against dictator Anastasio Somoza next door, and the Sandinista revolutionaries who took power in mid-I979, launching that country into a decade of hostilities with Washington, which funded a rural campaign of terror by counterrevolutionary guerrillas. In El Salvador, meanwhile, an ultraconservative coalition of landowners and military officers, alarmed by events in Nicaragua, relied on death squads and rural militias to repress a growing, Catholic-inspired movement for political and economic reforms. The relative international invisibility of El Salvador prior to 1980 provided a kind of carte blanche to the military government's excesses. When newly elected U.S. president Ronald Reagan "drew a line in the sand" and vowed to defend El Salvador's tiny upper class against revolution, that small country vaulted to center stage in the geopolitical arena. From I979 to I983 thousands of dissidents went underground to evade the state repression, feeding the ranks of the growing FMLN guerrilla army and their supporters. 


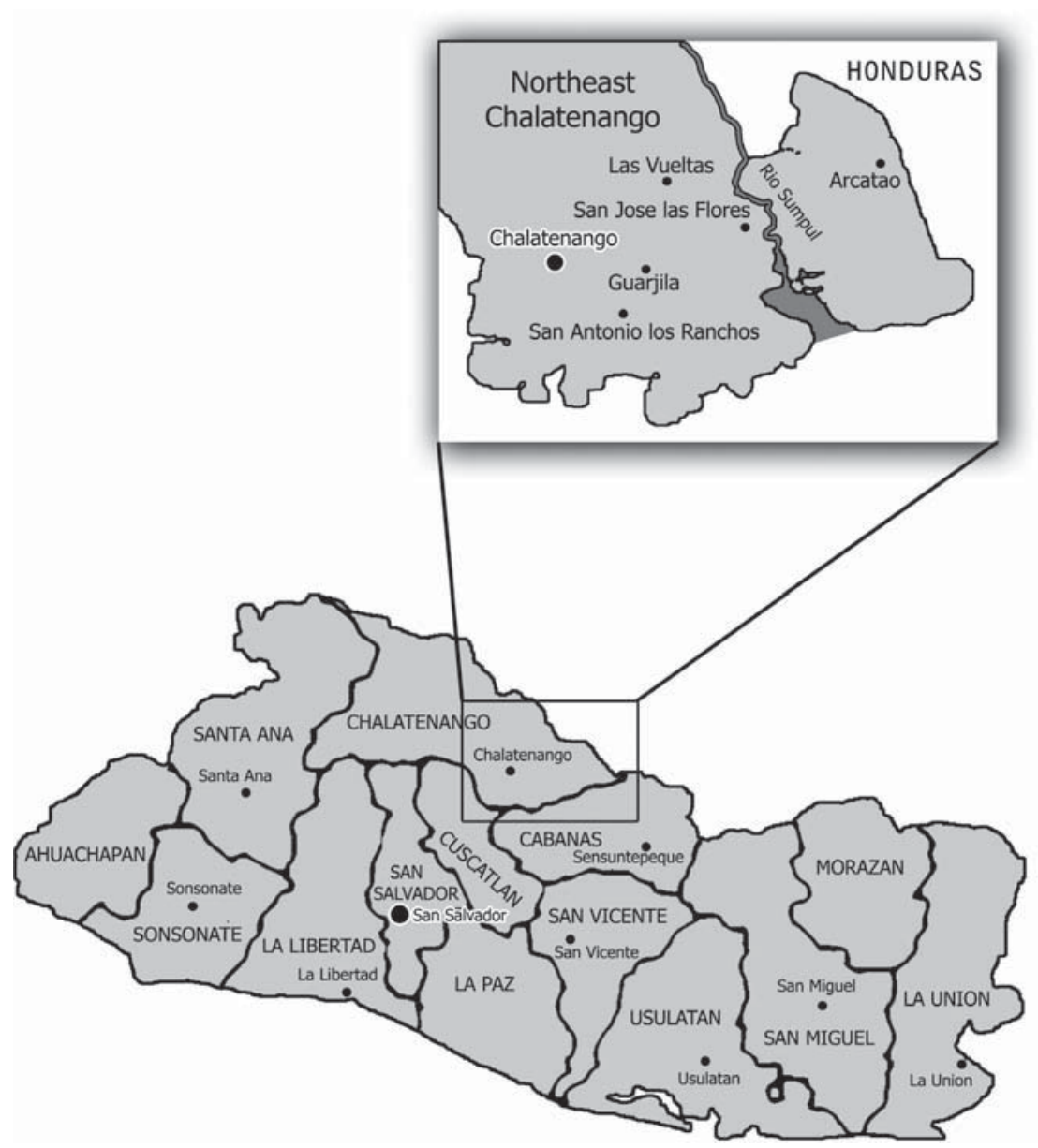

El Salvador with inset map of Chalatenango. Map by Roque Smith-Nonini.

The new U.S. military intervention spurred my initial involvement in 1982 when, as a young medical writer, I attended a meeting of doctors and nurses in a Washington, D.C., living room to discuss how to send medical aid to war refugees in Central America and publicize the destructive aspects of intervention for the public health. I was new to activism, but like many citizens I was moved by the bloodbath on the nightly news in the aftermath of Archbishop Oscar Romero's I980 assassination and the rape and murder of four American church women in 1979. Reagan's portrayal of the conflict as a Cold War conflict driven by Marxist-Leninists led to confusing media coverage that ignored the role of poverty and longstanding class divisions in the region's turmoil. Many of my medical colleagues had been influenced by the 1978 Alma Ata declaration on primary health care, which asserted that development goals become irrelevant 
if a population is unhealthy. Community-based health and other development initiatives were central to the Catholic Church's Liberation Theology activism in Central America, which condemned military repression against efforts to organize poor communities around the pursuit of reforms. By I980, human rights critiques had gained traction in the media, but the notion that impoverished peasants might claim economic rights to basic resources like food, medical care, and a safe environment seemed like so much pie in the sky.

I made several reporting trips to the region, most on freelance assignments for American Medical News, or with small delegations of U.S. doctors and nurses volunteering with the National Central American Health Rights Network (NCAHRN). We found that not only was it difficult to deliver medical aid to civilians caught in war zones, but increasingly the traditional "neutrality" of medical work was threatened because the Salvadoran military and its affiliated death squads viewed all civilian work with poor peasants as "subversive." It was not until I moved to San Salvador in 1987 that I gained some understanding of what Salvadorans euphemistically called la situación. So it makes some sense to start with this experiential foray into chaos and the surprising (dialectical) "other" side of a civil war-the human capacity to resist terror and to rebuild community. Like other foreign correspondents, my life in a middle-class neighborhood of the capital was protected from the day-to-day vagaries of poverty and violence experienced by most Salvadorans. It was on visits with colleagues to the embattled countryside when the scales of privilege fell from our eyes, and we were able, at times, to feel in our own bones the fear, moral outrage, and courage of life in El Salvador's "conflicted zones," as the areas of leftist guerrilla activity were known.

The extremes of terror and healing describe well the tenor of two excursions I made to Chalatenango in I989. This was the year that the ARENA party gained the presidency, leading to a new military crackdown on dissident groups. During the previous four years, the Salvadoran government, headed by the more centrist president Napoleón Duarte, had been pressured by the Democrat-controlled U.S. Congress to improve its dismal human rights record (ironically) so that legislators could justify approving U.S. military aid for Reagan's war against the insurgency. This scrutiny had created a political opening that was exploited by Salvadoran dissident groups, which held numerous street protests and posted ads in newspapers demanding peace talks, the release of political prisoners, and social programs for the poor. Leaders of ARENA insisted that dissident labor, human rights, and reformist groups were lackeys for the FMLN, which by now was a full-fledged guerrilla army with an estimated ten thousand fighters.

Both excursions I recount here were illegal, involving long overland hikes. By early 1989 the Salvadoran army had stopped issuing safe-conduct passes (salvoconductos) for journalists to visit "conflicted" rural areas, and my experiences on both trips were tinged by an acrid overlay of fear that we would be fired 
on by government soldiers. The first excursion, in February, was thrown together hastily. At a press conference, army officers had boasted that their elite (U.S.-trained) Atlacatl Battalion had killed eight FMLN "terrorists," and the army claimed to have "dismantled" a clandestine hospital in a place called El Coyolar, near the Honduran border. The army provided local media with photographs of confiscated medical supplies and the passport of a Mexican woman identified as Alejandra Bravo Betancourt, a doctor killed in the attack.

If the Atlacatl Battalion had intentionally destroyed a medical clinic, it was an egregious violation of international law, which states that health facilities and personnel should be protected in war. However, the Geneva Conventions were routinely violated by the Salvadoran military. At the time, I was preparing a report on such violations for American Medical News, and here was the army bragging about killing a doctor. None of my journalist colleagues planned to investigate because no one knew how to locate the site. Before dawn the next morning I set out with a photographer, whom I will call Terry, in a jeep headed north. We talked our way through an army roadblock, telling solders that we were covering an ARENA party election rally scheduled in the departmental capital later that morning. Instead, we turned west, passing through Dulce Nombre de María, and then north, winding around pine-covered mountains on a poorly maintained dirt road.

The road abruptly ended at the tiny village of Ocotal, only a few miles from the border. We had no idea where to go next. That afternoon we sat in on a "liberation theology"-style meeting led by a catechist where local youth planned a festival. Enthusiasm was muted as everyone compared rumors about the "massacre" at the FMLN mobile clinic and the alleged brutal murder of "Julia," a guerrilla doctor known to the villagers as someone they too had counted on from time to time when she was needed to treat sick or wounded civilians. The rumor was that a total of ten patients and health workers had been killed in a surprise ambush. Ocotal residents were angry but pleased that reporters had come from the capital to investigate.

We casually mentioned that we would need help finding the site. The catechist helped us set up canvas cots in the small church, where we spent an uncomfortable night being bitten by fleas. The next morning a young man knocked on the door and handed us a note directing us to hike to a hill outside of town. There we were greeted by "Manuel," a skinny ten-year-old in a ragged tee shirt and long pants who told us that he was an FMLN correo (messenger). Manuel took us in tow, and for the next three hours we struggled to keep up with him as he scampered across creeks and up steep hillsides like a goat with no apparent effort.

A half hour into our hike, woods gave way to a sunny meadow, where two streams of guerrilla fighters casually crossed the clearing in front of us on intersecting paths. They were young men and women dressed in jeans and fatigues 
and with backpacks and bright bandanas, each with the ubiquitous rifle slung on their back. They looked serious but friendly and nodded to us as they passed.

What we anticipated to be a short hike turned into hours of trudging up and down an endless succession of hills, each seemingly steeper than the one before. We took turns carrying Terry's camera gear. At midday we passed several abandoned villages, then skirted the side of a scorched hillside, and stopped at a lone adobe-walled house that Manuel declared our destination. Inside, campesino women worked around a fireplace, grinding corn and cooking red beans. FMLN combatants came and went on a rocky trail that emerged from a ravine behind the house.

Manuel ran off and came back a few minutes later with two robust, bearded guerrilla fighters, who introduced themselves as Miguel and Edgardo. The two sat down with us on a rock wall outside the house to answer our questions while polishing off two cans of sardines that we dug out of our packs as an offering. Miguel recounted that on the day of the attack he had watched in a helpless fury from a nearby ridge as Atlacatl commandos ignored existing trails and penetrated straight across a stand of dense scrub forest to reach the mobile open-air "hospital," which was hidden in a cave-like rock formation. "It was as if they had knowledge of the exact location of the clinic," he said (a fact that I confirmed years later from a former guerrilla who said the clinic's location had been revealed to the army by an informant).

Miguel was distraught that his compañeros had been unable to get a warning to the health workers, who had been temporarily left without an armed guard. The soldiers, undetected by the medical staff, had taken the time to set up an M6o machine gun looking down on the open-air medical encampment. Miguel and Edgardo confirmed the villagers' account of a ten-person death toll, which included the doctor, three nurses, and six patients, figures later verified by Tutela Legal, the human rights office of San Salvador's archdiocese, which sent a delegation to exhume the bodies. Two campesino men described how they had followed a blood-stained trail to locate the hacked up and naked bodies of "Julia" and a Salvadoran sanitaria (health aide), both of whom fled when the soldiers opened fire. One led Terry to their gravesite to take photographs.

Getting out of the conflicted zone proved more difficult than entering. After an exhausting five-hour hike, Manuel left us in the woods near Ocotal. The next morning as we turned onto the last stretch of gravel road leading to the Troncal Norte highway, we found our way blocked by two army jeeps with a bar lowered across the road. We spent the rest of the day detained in the fortified headquarters of the Army's Fourth Brigade headquarters while soldiers searched the jeep and belongings, asking us repeatedly where we had been and why.

The following June I found myself once again undertaking a day-long hike through a no-man's land of dense forest, rocky hillsides, and abandoned hamlets. Our goal this time was not to verify horrors but rather to witness the drama 
of former refugees determinedly carving a neutral zone by rebuilding bombedout villages in disputed territory. Beginning in 1987 thousands of refugees, some of whom had spent years in refugee camps, returned in huge caravans to conflicted zones of El Salvador with the goal of resettling their abandoned villages. The new civilian presence in northeastern Chalatenango, a rearguard area for the FMLN (and our destination that June day), was a thorn in the side of the Salvadoran government. From 1983 to 1986 the army, guided by U.S. military advisors and armed with U.S-built aircraft, had bombed and strafed all traces of human presence in this zone. As intended, these "scorched earth" tactics had driven most peasants into exile or urban displaced person camps. The widely publicized return of civilians under the vigilance of human rights groups and United Nations observers greatly complicated the government's military strategy.

Our small contingent was made up of three journalists (a Salvadoran filmmaker, an Argentine reporter, and me), a local guide, a peasant woman, and her teenage son who rode a mule because he had lost a leg in a mine explosion. I remember that we circumvented a bomb crater and a burned patch of ground, the aftermath of an air raid, as we approached the settlement of Guarjila around 9 P.M. I was so exhausted I nearly sat down in the road.

Over the next two days, on visits to two resettlement villages, we were amazed to find that, despite makeshift housing and poor infrastructure, residents seemed to be socially thriving, with a strong sense of unity and determination to rebuild their lives. Evincing none of the wariness of strangers one often encountered in rural villages, the ex-refugees of Guarjila embraced us warmly, fed us dinner, and gave us space in the hut next to the community kitchen to spread our bedrolls on the ground. We stayed up late discussing politics with Antonio, a local guerrilla officer who stole into town after nightfall. The cook greeted him with a bowl of scrambled eggs and rice, and we joined him at the picnic table peppering him with questions about the war and frustrated peace negotiations. The night was pitch black, the only light coming from Antonio's cigarette and a small flashlight, which he turned off and on, carefully shielding the beam.

The next day I interviewed a man whose seven-year-old daughter had been shot in the side a few days earlier when a helicopter machine-gunned roofs of the village. Local health "promoters" operated out of a tiny shack with a handful of medicines, which were still treated as contraband at army roadblocks. Horses and mules were lent to us for the forty-minute journey to San José Las Flores, a more established village, where we learned that the local clinic had recently been forcibly occupied by soldiers, and several dental promoters had been captured and tortured by the army. Yet in the midst of these fearful accounts, we were being shown around by men and women with hopeful spirits, proudly ticking off their achievements-a new birthing room, a child care center, a cattle 
cooperative, and (marginally stocked) community stores. Here was truly a story of healing in the midst of terror. Both nights we attended outdoor dancesa surreal scene as young men, rifles clacking on their backs, swayed to poor recordings of American rock songs opposite civilian women in cheap polyester dresses; then the gendered norms were flipped as female guerrillas joined the dance in berets and tight khaki skirts.

We debated how to get back to the capital. I argued against hitching a ride since the few vehicles leaving the zone were routinely searched at government roadblocks. I feared the military would revoke my (army-issued) press credentials (given my previous arrest). We were lucky. Two jeeploads of European VIP's came to visit the resettlements, and they agreed to smuggle us out. At the roadblock we cowered in the rear when the soldiers asked to see IDs, but the driver waved foreign credentials and faced them down with splendid French arrogance. "In like bandits and out like diplomats," crowed my Argentine friend that night over beer.

Tension worsened in November 1989 when a guerrilla offensive brought the war to the capital. The military responded with raids on dissident groups and air attacks on urban barrios. Then an army squad murdered six Jesuit priests who were prominent social scientists at the University of Central America and advocates for economic reforms. The same week, I received telephoned death threats, as did another reporter.

In early I990 I moved back to the United States. I did not return to Chalatenango until shortly after the U.N.-mediated ceasefire in I992. Now a graduate student in anthropology, I was eager to discover what had become of the lay health workers who had so impressed me during that 1989 visit. It was a giddy feeling entering the former war zone in bright sunlight on a rickety little bus weighted down with sacks of corn, chickens, women, and children-light years removed from the tensions of the war. How strange to pass the site of the army roadblock under the old conacaste tree. No soldiers. No guns.

As we came within site of Guarjila's neat bajareque buildings, a campesino directed me to the new health clinic. The neat nine-room cinderblock clinic and adjacent small "hospital" easily qualified as the nicest buildings in town, with a bright interior lit by clear plastic panels in the roof. Women and children sat on benches inside, and three female promoters bustled about taking histories and peering at sore throats. Inside a woman physician from Boston was attempting to help but was hampered by her broken Spanish. I offered to translate. In the examining room a teenage boy lay on a table, his hand disfigured by a huge swollen abscess. Jennifer conferred with Lucia, the twenty-two-year-old health promoter, about the case and shook her head, suggesting that the boy be sent to a government hospital in Chalatenango, the departmental capital.

"No, I know how to take care of it," said Lucia. The physician stepped aside and watched as the promoter proceeded to give the boy an intramuscular 
injection of ketamine and waited until he fell asleep. Then she competently lanced the abscess with a scalpel and drained the pus into a pan. Throughout the procedure she kept a hand pressed to the boy's chest monitoring his heart rate. Afterward she started him on antibiotics.

Leaving the examining room afterward, Jennifer's eyes met mine with a look of amazement. She remarked, "Lucia even knew to give him Atropine and Valium to counteract psychological effects of the Ketamine. In the hospital where I work we would have called in a specialist!" While observing health practices in the weeks to come I learned that draining abscesses was a routine procedure for Lucia, who, as a former paramedic with the FMLN, had often assisted with complex surgeries in the field. The "popular" system was backed up by a small technical team of traveling physicians and nurses, but day-to-day health care in most villages, including routine diagnoses and prescribing, was the responsibility of competent lay promoters like Lucia, many of whom were only now, in the aftermath of the war, getting a chance to complete their primary education. 

Healing the Body Politic 
